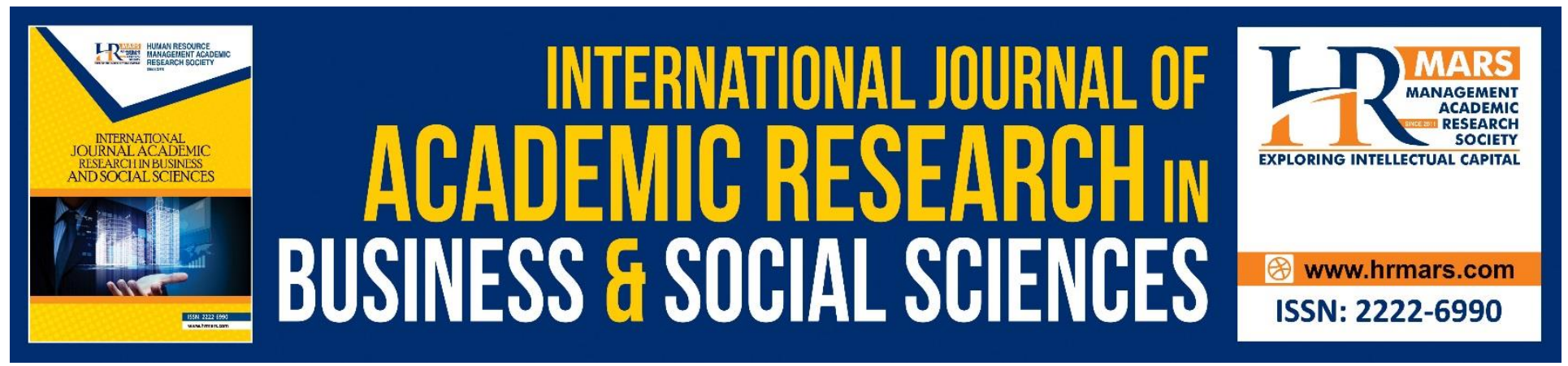

\title{
Islamic Counselling: An Integrated Approach in Promoting Psychological Well-Being
}

\section{Nooraini Othman}

To Link this Article: http://dx.doi.org/10.6007/IJARBSS/v9-i3/5727

DOI: $\quad 10.6007 /$ IJARBSS/v9-i3/5727

Received: 12 Feb 2019, Revised: 16 March 2019, Accepted: 30 March 2019

Published Online: 11 April 2019

In-Text Citation: (Othman, 2019)

To Cite this Article: Othman, N. (2019). Islamic Counselling: An Integrated Approach in Promoting Psychological Well-Being. International Journal of Academic Research in Business and Social Sciences, 9(3), 578-588.

\section{Copyright: (c) 2019 The Author(s)}

Published by Human Resource Management Academic Research Society (www.hrmars.com)

This article is published under the Creative Commons Attribution (CC BY 4.0) license. Anyone may reproduce, distribute, translate and create derivative works of this article (for both commercial and non-commercial purposes), subject to full attribution to the original publication and authors. The full terms of this license may be seen at: http://creativecommons.org/licences/by/4.0/legalcode

$$
\text { Vol. 9, No. 3, 2019, Pg. } 578 \text { - } 588
$$

Full Terms \& Conditions of access and use can be found at http://hrmars.com/index.php/pages/detail/publication-ethics 


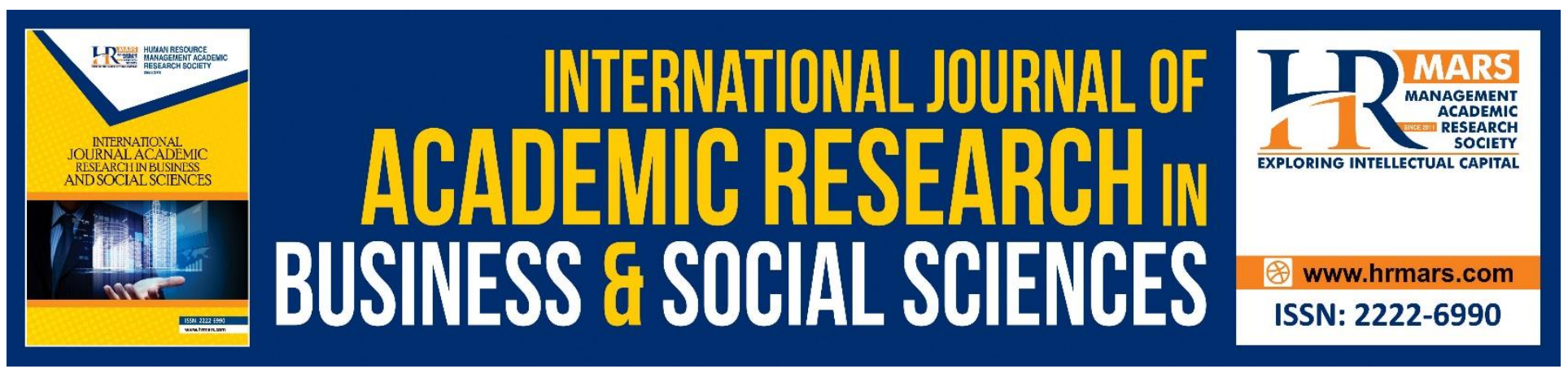

\title{
Islamic Counselling: An Integrated Approach in Promoting Psychological Well-Being
}

\author{
Nooraini Othman \\ Perdana Centre of Science, Technology \& Innovation Policy, Razak Faculty of Technology and \\ Informatics, Universiti Teknologi Malaysia \\ Email: p-noraini@utm.my
}

\begin{abstract}
The aim of this paper is to highlight the role of Islamic Counselling in promoting the psychological well-being in the society. Its integrated approach being applied in the counselling session involving the Muslim clients allows the counsellor to play a better role and perform more effective as compared to the conventional counselling. The three main elements in counselling adopted from Carl Rogers which is widely accepted to be practised during the counselling session are empathy, congruence and unconditional acceptance. Accommodation of the psycho-spiritual elements in Islamic Psychology which is Ibadah (Motivation), Amanah (Self-Concept) and IIm (Intellect) are important in developing the Islamic personality of the counsellors. These elements will be able to strengthen their capability in handling the psychological issues faced by the Muslim clients. The development of a strong Islamic personality in a Muslim counsellor would certainly contribute to the positive character building of the clients which finally enable them to independently achieve their psychological well-being. Finally, this paper concludes the discussion by presenting the newly developed model namely, Integrated Approach of Islamic Counselling Model (IAICM).

Keywords: Islamic Counselling, Integrated Approach Model, Islamic Psychology, Psychological Wellbeing, Psycho-spiritual
\end{abstract}

\section{Introduction}

Counselling refers to an interpersonal relationship which involved a form of interpersonal interaction between a congruent, knowledgeable as well as skillful individual (counsellor) to understand and assisting another individual (client) in solving his personal issues. Counselling will take place if an individual seeks psychological help from a qualified and registered person to handle a counselling session in order to discuss certain issues involving conflict or dilemma which prevent him from enjoying his life. Normally, an individual will only seek for help when they could not solve their own issues and this situation prevents him from performing his normal functions in life. As a counsellor, there are certain important and significant characteristics which are expected from him 
or her. Among them is unconditional positive regard of the client, congruent, empathy and honesty (Rogers, 1980). These characteristics form a basis for personality development among the counsellors. Generally, counselling is primarily concerned with the well-being of the mental health. The goals of counselling as stated by Corey (2013) are to change an individual's thought, feelings and behaviour.

A Muslim counsellor who works and performs only to seek the blessing of Allah throughout his whole life will always strive his best to help and assist his clients in the best possible manner, using his best to gain more knowledge, to master the counselling techniques and upgrading his skills to suit the needs of his clients. To be effective, counsellors should exhibit generic characteristics such as good psychological health, self-awareness, open-mindedness, having empathy, unconditional positive regard, genuineness and congruence, non-judgemental, cultural sensitivity and competence (Rassool, 2016). These characteristics, when couples with the Islamic spiritual elements would certainly bring better outcome to the counselling sessions. As concluded by Rassool (2016), Islamic counselling is a consciousness awareness of God in the counselling process in which it is based on the implicit understanding of a mutual belief system (Islam) shared by both the client and counsellor, which creates a trusting relationship between them. Thus, the practice of Islamic spirituality in the counsellor self, heart, mind and soul will develop a counsellor with Islamic personality and become the role model to his or her clients.

\section{Role of a Counsellor}

The counsellors play a very important role in helping their clients to overcome or manage their symptoms with the guidance. They could also help in developing strategies and skills such as coping mechanism in order to minimize as well as manage the psychological effects of the issues. Other than becoming an active listener, the counsellor should be able to help the clients in managing their stress by turning it from a disturbance into a motivation. The ability to develop resilience and inner strength among those affected by the mental health issues would certainly enable them to prevent themselves from further self-destruction.

In general, counsellor serves as a helping hand to those who face psychological issues and they need somebody else to assist them in trying to overcome or even solving their issues. They need someone who has counselling knowledge, acquire related skills and techniques and the most important of all is a counsellor with good personality. Counsellor with good personality will keep the trust and will try his best to be the helping hand. Thus, Islam urges the Muslim to develop good personality to be the role model to his fellow beings.

As a counsellor, there are several principles which are widely practiced by the counsellors all over the world. The main three as promoted by Rogers are empathy, congruence and unconditional positive regards. Empathy involves the ability to emotionally understand what another person is experiencing. Essentially, it is putting you in someone else's position and feeling what they must be feeling. Congruence also refers to genuineness. Being congruent is being in touch with and genuine about own experience - with ourselves and with our client. Being congruent means staying connected with self, client, space and time and to share a persistent thought or feeling. The counsellor who practices unconditional positive regard towards his client has deep and genuine caring for the client. He may not approve of some of the client's actions, but he does approve of the client. In short, 
INTERNATIONAL JOURNAL OF ACADEMIC RESEARCH IN BUSINESS AND SOCIAL SCIENCES

Vol. 9, No. 3, March, 2019, E-ISSN: 222 2-6990 @ 2019 HRMARS

the counsellor needs an attitude of "I'll accept you as you are." The person-centered counsellor is thus careful to always maintain a positive attitude to the client, even when disgusted by the client's actions.

\section{Role of an Islamic Counsellor}

Counseling in Islam emphasizes the biological, social, and spiritual aspect of individuals (AlThani, 2012). It emphasizes religious and cultural values. It also emphasizes the importance and beneficial effects of the family and social bonds against all-out individualism and selfish concerns. The functions of the Muslim counsellors are closely related to their goal in life, personality and characters. Nobody could deny that their responsibility to help their clients in achieving the psychological balanced and well-being is a big contribution to the client's current and future life. It is already Islamic in nature. Not only his own life but also his family, the society as a whole and the most important is his aqidah. There are several writings (Al-Thani, 2012; Hamjah \& Mat Akhir, 2013; Zayed, 2014) discussing about Islamic Counselling in their own ways.

The present author has her own stand and understanding in relation to the role of an Islamic counsellor. Being Muslims, our approach is always to practise Amar Ma'aruf Nahi Munkar (ordering right, prohibiting wrong) (Surah Al-Imran, verse 104). As an Islamic counsellor, the role of helping clients who are facing the psychological issues is considered as the curative action. By applying the concept of Amar Ma'aruf Nahi Munkar, we are doing the preventive measure in assisting the client to develop the inner strength and capability to prevent them from doing harm to their deen, nafs, aqal, mal and nasab (Al-maqasid As-Shariah).

Having to be tested by Allah (both the counsellor and the client), the concept of Muhasabah plays such an important role as a method of self-introspection as well as self-reflection to our past and current practice in our life. Non-judgemental attitude in assessing our client and us will make the counselling process to be a therapeutic and valuable one. Another important aspect is Islah. Having to identify and reflect his or her own deeds, it is vital for the counsellor to help the client to get back to the fitrah of a human (man is not born evil, he is vulnerable to evil stimuli or external sources of misguidance). Thus, self-improvement would be one of the best methods to correct the wrong doings. The goal of Islamic counselling is finally to gain the blessing of Allah through the Islamic practice of the counsellors in assisting their clients to be a blessing to themselves (psychological wellbeing), their family (healthy relationship) and their environment (Rahmatan lil 'Alamin).

\section{Integrated Approach in Islamic Counselling}

The present author believes that counselling is already Islamic in nature. The acts of helping, assisting and relieving someone from the psychological issues that they are facing is part of amal $m a^{\prime}$ aruf which is under the obligations of all Muslims. As long as the techniques applied in conducting the session do not contradict with the syariah laws and regulations, there is no harm being done. To ensure that the elements or the principles of the Islamic counselling can be internalised, focus should be given to the development of Islamic personality of the counsellor.

The author proposed an integrated approach in Islamic counselling through the combination of psycho-spiritual aspects of Islamic personality namely, Ibadah, Amanah and IIm (Othman, 2011; 2016) and the counselling principles, which is, unconditional positive regard, congruence and 
INTERNATIONAL JOURNAL OF ACADEMIC RESEARCH IN BUSINESS AND SOCIAL SCIENCES

Vol. 9, No. 3, March, 2019, E-ISSN: 2222-6990 @ 2019 HRMARS

empathy. These combinations would produce spiritual competencies namely, sincerity, acquaintance and wisdom.

According to Othman $(2011 ; 2016)$ in her previous writings stated that the psycho-spiritual aspects of personality and spiritual competencies development are Ibadah, Amanah and IIm. These aspects are discussed in detail as follows.

\section{Ibadah (Worship/Submission) and Ikhlas (Sincerity)}

Ibadah is generally understood as worshipping Allah. It is also understood as a total and pure submission to Allah, spiritually and physically. Spiritual refers to the heart element and factor. By physical we mean the bodily action. It is the very purpose of the creation of mankind. Allah says in the Quran (Az-Zariyat: 56):

"I did not create Jinn and human except that they should worship Me".

For acts or deeds to be considered as ibadah, they must fulfil the minimum of two basic criteria. Firstly, it is done with all sincerity (ikhlas) for the sake of Allah alone. Naturally it is done with a pure intention (niah), which has the ultimate connotation 'for Allah alone,' (lillahi ta'ala). No other elements should interfere with the purity of sincerity. Secondly such deeds or acts must be done in conformity with the prescription of the syariah. It means that a careful observation of what is right in the eyes of Islam must be made. In other words the end does not justify the means.

Ibadah is not only limited to the specific acts of rituals such as solat and zakat. In actual fact, all activities of Muslims can become ibadah, right from the moment they wake up in the early morning until such time they wake up again the following morning. In essence, it is in itself a motivation for one to be obedient to Allah and to be mindful of the limits set by Him as we understand in the concept and context of taqwa and ihsan. Through ibadah one is motivated to make every attempt to do things which are right and in the right way. Another aspect of motivation is when one hopes and expects for the pleasure of Allah (ridho). With the blessings of Allah (rahmah) one would enter paradise (jannah) in the hereafter. These are all motivations as a result of ibadah.

In a more profound context, Langgulung (2001) explains that ibadah is the actualisation of the Divine qualities in men so that they can perform their duties as 'slaves', which also means that a human's entire life is ibadah. He elaborates that the term ibadah also means the development, actualization and manifestation of man's hidden potentials that can be derived from the attributes of Allah that lay dormant within man. He further explains that the spiritual motivation found in the Quran, which explains the concept of human life as an ibadah, can be a dynamizing force in directing all man's actions toward perfection and righteousness. All the pleasurable things promised by Allah for the true believers can produce a man who is patient and persistent in facing all the trials and tribulations in this life. Allah says in the Quran (Al-Insan:12-13):

"And because they were patient and constant, He will reward them with a Garden and (garments of) silk. Reclining in the (Garden) on raised thrones, they will see there neither the sun's (excessive heat) nor (the moon's) excessive cold".

Ibadah is a motivation for every self to fulfil the responsibilities or duties to the Creator. Ibadah signifies that a person fully submits himself to the will of Allah. His aim in life is to secure the blessings and pleasure of Allah. By that he becomes motivated to fulfil his promise which is uttered regularly a 
minimum of five times daily in his prayer, "verily my prayer, and my worship, my life and my death are all for Allah." He will do so without neglect of what is obligated upon him being his personal responsibility, namely fardhu 'ain, and to participate in his religious duty. What is compulsorily is to be done in congregation with the understanding that no one is freed from liability if such an ibadah is not collectively performed. This is fardhu kifayah.

Certainly, a Muslim that cares for himself well and manages the affairs of his community effectively is a good and responsible Muslim. His belief in the rewards of Allah, which include a good life in this world (hayatan toyyibah) and paradise in the hereafter (al-jannah), becomes a consistent motivation to turn his whole life into ibadah, in a comprehensive and holistic manner.

\section{Amanah (Trust/Accountability) and Ma'rifah (Acquaintance)}

Amanah is the performance of trust. Being the khalifah of Allah on the face of this earth, a person is shouldered with responsibilities to be performed. The performance of trust represents the true value of a Muslim as Prophet Muhammad said,

"No Iman (faith) to one who has no amanah (trust) and no Deen (religion) to one who dishonours his promise". (Al-Bukhari)

The world is a safe place when everyone performs and enjoins goodness (amal ma'ruf) and forbids evil deeds (nahi munkar). They are noble tasks and the essence of da'wah (call of Islam). Being khalifah, this trust must be performed to everyone's level best. In the Quran (3:104), Allah commanded that,

"Let there be of you an ummah to call to the good, to enjoin virtue and forbid vice. Those who do so are the felicitous".

Amanah symbolises integrity. Human civilisation will collapse and the fabric of the community will be torn apart when integrity is absent and the worst nightmare is when corrupt practices are rampant. Amanah also symbolises honour. One will lose his honour the moment he is in breach of trust. No one could escape being accounted for his deeds in this world. Accountability rests with Allah and human being. The cleverest may escape from human sights but no one could do that with Allah. If mankind decides to be al-Amin (the trustworthy), it is only for the goodness of human civilisation. In the Quran (Al-Baqarah: 30), Allah explains that He created mankind as khalifah on the face of the earth:

"And when your Lord said to the angels verily I am creating on the earth khalifah"

Being khalifah they are accorded with the responsibility of prospering (imarah) the earth. In the Quran (Hud: 61), Allah says:

"And He is (you Lord) who gives you lives from earth and makes you the prosperor" 
This is a clear command of trust from Allah to mankind. It is a responsibility that will be accounted for. The Prophet regarded us as trust bearers ( $\left.r a^{\prime} i n\right)$, which can translate as leader:

"Everyone of you is a trust bearer (ra'in) and everyone of you will be responsible for their trust". (Bukhari and Muslim)

Rashid (2005) stated that beside the mission to worship Allah, man was created to perform crucial and creative duties on earth as khalifatullah. As khalifatullah, man is given the amanah which the other creatures refused to accept because they were unable to bear its heavy responsibility.

Ansari (2001) stated that being a khalifah, his ibadah should not be confined only to the act of prayer but also to: 1 ) the development of his personality in all dimensions; 2 ) the establishment of a godly society in which human beings can live a full and integrated life in love, justice and wisdom; and 3 ) the unraveling of the mysteries of Nature for establishing his status of khalifah and for comprehending the majesty and glory of God.

According to Islam (2000), the very essence of human personality is that he is congenitally pure, flawless and supremely noble, capable of reaching the highest pinnacle of moral excellence and the highest degree of perfection, both spiritually and ethically. This is well stated in the Quran (AtTin: 4-6):

"Surely we have created man in the best of moulds. Then we render him the lowest of the low, except those who believe and do well so that they shall have self-perpetuating reward".

He further explains that man enjoys superiority over other creations of Allah in the sense that it is only he who opted for shouldering the trust and responsibility of the freedom of will which enables him to make choices and be accountable for his actions. This is one of the fundamental traits of man's personality in which none other had the courage to do that. This has entitled him to shoulder the responsibility of being khalifah. The Quran (Al-Ahzab: 72) states that:

"Surely we offered the trust (responsibility) to the heavens and the earth and the mountains; but they refused to undertake it, because they were afraid of it".

In essence, the self-concept of man, being who he is and why is he on earth must be fully understood and appreciated. Ma'rifah means the recognition and consciousness of Allah. If a person is conscious of Allah, he will abide by the laws of Syariah. Thus, the achievement of Ma'rifah through the realisation of the purpose of human creation, his responsibility and the concept of accountability will give way to development of congruency in the human life.

\section{IIm (Intellect) and Hikmah (Wisdom)}

In addition to Ibadah and Amanah, IIm is another important aspect of human civilisation. Knowledge is an enabler. For example, knowledge enables civilisational development. Knowledge enables many improvements. A knowledgeable person would be able to find the path for him to be 
closer to Allah and to be righteous to the ummah. Knowledge symbolises power (sulton). A man with knowledge will be able to overpower his lustful desires (nafsul ammarah). A knowledgeable person would also be powerful enough to surpass the boundary of heaven and earth (as-samawat).

What is important is for a person to acquire as much knowledge as possible while at the same time being closer to Allah. What is equally important is for such knowledge to be put into good practice. An Arab proverb says, "Knowledge without practice is like a tree without fruit." The very first verse revealed by Allah in the Quran speaks about knowledge. The verse reads iqra', which means proclaim or read. In the Quran (Al-Alaq: 1-5), the meaning of the verses is as follows:

"Read! In the name of thy Lord and Cherisher, Who Created. Created man, out of a clot of congealed blood. Read! And thy Lord is most bountiful. He who taught (the use of) the pen. Taught man that which he knew not".

In the previous work (Mohamad \& Othman, 2004), it was explained that the significance of the above verses is tremendous. They spell out clearly the ingredients of civilisational development. Knowledge is the wisdom derived from the Quran. That is the researcher's understanding of its epistemological basis.

Firstly, before Jibril read out the first verse to Prophet Muhammad, on three occasions the Prophet was instructed to read but he replied that he does not know how to read for he was illiterate. Each time the prophet responded to him, the Prophet was hugged. This event signifies that a learning process must be methodical. The process of instructing, hugging, responding and conveying has become an integral part of education. It involves the elements of commitment to students as well as emotion, care and psychology. The methodology of conveying knowledge is as important as the knowledge itself. Today, it is translated in the form of pedagogy and also educational psychology. It also explains that learning is a process involving two-way communications, which are sometimes instructional.

Secondly, iqra', being the first revelation is a command to read. Reading has always been associated with knowledge acquisition. Civilisational development has equally been associated with knowledge development. Allah says in the Quran (Al-Mujadalah: 11):

"Allah will promote those among you who are faithful and those who possess knowledge to higher status".

The quality of the ummah is equally promoted and given serious attention. It is evidenced when, iqra' is immediately followed by bismi Rabbi-ka-l-ladhi kholak, which means in the name of your Lord (Allah) who is All-Creating. This is where the reference to Tawhid is its overriding criteria. It means that knowledge should lead one to the path of God and appreciate His Greatness. The higher the knowledge, the closer one should be to Allah. A person will become more faithful and pious as a result of this realisation.

The central idea is that knowledge should be put to good use serving mankind, and not to cause destruction on earth. This is in line with the reminder of Allah in the Quran (Ar-Rum: 41): 
INTERNATIONAL JOURNAL OF ACADEMIC RESEARCH IN BUSINESS AND SOCIAL SCIENCES

Vol. 9, No. 3, March, 2019, E-ISSN: 222 2-6990 (C) 2019 HRMARS

"Mischief has appeared on land and sea because of that the hands of man have earned. That (Allah) may give them a taste of some of their deeds, in order that they may turn back (from evil)".

This verse actually speaks about human development. The humanity of man must be raised to the highest level and cherished. A good man puts his knowledge to good use. This person is always mindful of the limitations set forth by God. Such mindfulness coupled with proper conduct will turn all the activities in to ibadah.

For one to pass the boundary of excellence in knowledge, it is not sufficient if it is just being done through reading and visual observations. It could only be achieved through detailed analysis of a given issue or subject matter and followed by written works. According to Safi (1996), the primary task of the intellectual is to develop a vision based on the principles of truth, to identify the set of values and goals associated with this vision, and to propose an appropriate model for the realisation of these values in actual life. The intellectual's motive to rediscover the truth emanates from the actual conditions of society, rather than theoretical considerations of a purely abstract nature. Thus, knowledge must be discovered for it is part and parcel of human personality formation. This is where the wisdom emanates and empowers the true life of human being.

\section{Conclusion}

The counsellor's realisation of his self, being the khalifah of Allah, with full awareness of the three aspects of spiritual competencies namely, sincerity (ikhlas), acquaintance (ma'rifah) and wisdom (hikmah) is expected to be able to pave the way towards Islamic Counselling. His service towards his clients is done with full realisation that it is an amanah on him to initiate the client's willingness either to exercise amal ma'aruf nahi munkar or muhasabah and islah in order to achieve the blessing of Allah.

Thus, in the end of the day, Islamic counselling is functioning as an integrated approach in helping people to achieve a holistic and psychological well-being with the development of balanced life in fulfilling the needs of five elements of human nature (jasad, aqal, qalb, ruh and nafs), possess high level of resilience to enable them in accepting and facing the challenges in life, be knowledgeable to enable the differentiation of what is good and what is bad. Finally, Islamic counselling aims to develop someone with strong characters to independently and continuously achieve the psychological well-being. Based on these concepts and understanding, the author develops a model namely, the Integrated Approach of Islamic Counselling Model (IAICM). 
INTERNATIONAL JOURNAL OF ACADEMIC RESEARCH IN BUSINESS AND SOCIAL SCIENCES

Vol. 9, No. 3, March, 2019, E-ISSN: 222 2-6990 ¿ 2019 HRMARS

The Integrated Approach of Islamic Counselling Model (IAICM) is summarised in the diagram below.

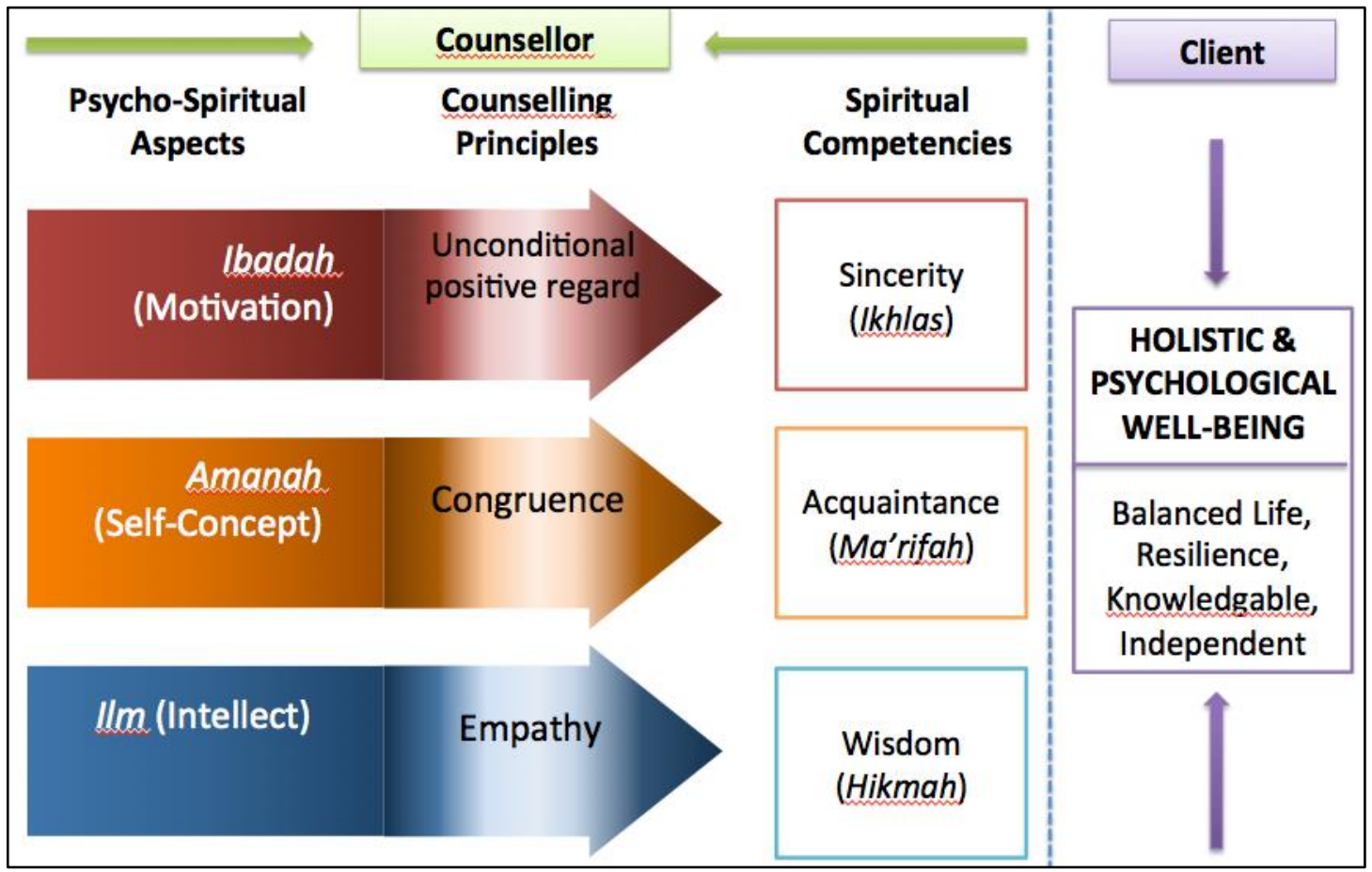

Diagram 1: Integrated Approach of Islamic Counselling Model (IAICM)

\section{Acknowledgement}

This research is currently sponsored by Ministry of Education Malaysia under the Fundamental Research Grant Scheme (FRGS 2019), Vot No. 5F018.

\section{References}

Rashid, A. A. (2005). Man's nature and his potentialities towards a good moral quality. Jurnal IKIM. $13(1), 41-54$.

Al-Thani, A. S. (2012). An Islamic modification of the person-centered counseling approach. Qatar: Qscience.com.

Ansari, M. F. R. (2001). The quranic foundations and structure of Muslim Society. Volume 1. Kuala Lumpur: Islamic Book Trust.

Islam, A. (2000). Islamic personality and its development. Muslim Education Quarterly, 17 (2), 61-68.

Corey, G. (2013). Theory and practice of counseling and psychotherapy. Belmont: Brooks/Cole, Cengage Learning. 
Hamjah, S. H. and Mat Akhir, S. (2013). Islamic Approach in Counseling. Journal of Religion \& Health, Vol. 52, No. 1, March 2013

Langgulung, H. (2001). A psycho-pedagogical approach to islamization of knowledge. Selangor: International Islamic University Malaysia.

Mohamad, K. A. and Othman, N. (2004). The concept of knowledge society and quality of life from the islamic perspective. Jurnal IKIM, Vol. 12, No. 2. Institut Kefahaman Islam Malaysia (IKIM)

Safi, L. (1996). The foundation of knowledge: A comparative study in Islamic and Western methods of inquiry. Petaling Jaya: International Islamic University Malaysia.

Othman, N. (2011). Exploring the Ummatic Personality Inventory Dimensions from the PsychoSpiritual Paradigm. International Journal of Psychological Studies. Vol. 3, No. 2, December 2011.

Othman, N. (2016). A Preface to the Islamic Personality Psychology. International Journal of

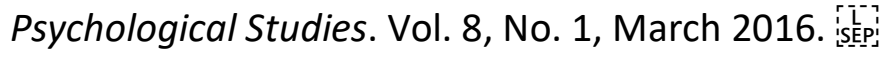

Rassool, G. H. (2016). Islamic couselling: An introduction to theory and practice. New York: Routledge/Taylor \& Francis Group.

Rogers, C. R. (1980). A way of being. Boston: Houghton Mifflin.

Zayed, T. M. (2014). Conceptual and practical understanding of counselling in Islam. Malaysian Online Journal of Psychology \& Counseling, Vol. 2, No. 1, April 2014. 